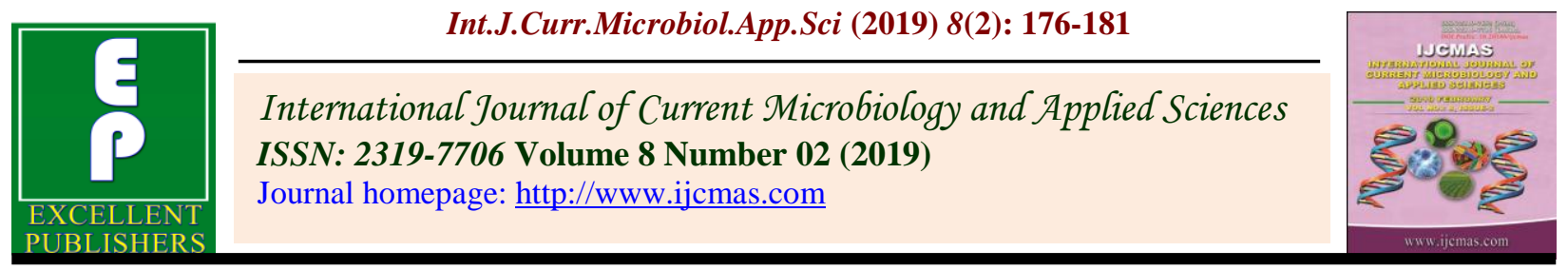

Original Research Article

https://doi.org/10.20546/ijcmas.2019.802.021

\title{
Combined Effect of Enriched Compost and Microbial Inoculants on Soil Nutrients and Phosphorus Uptake by Rice
}

\author{
Kasturikasen Beura ${ }^{1,2}$, Amit Kumar Pradhan ${ }^{2}$, \\ Goutam Kumar Ghosh ${ }^{1}$ and Anshuman Kohli ${ }^{2}$ \\ ${ }^{1}$ Department of Soil Science and Agricultural Chemistry, Palli Siksha Bhavana, \\ Visva Bharati, Sriniketan, West Bengal-731236, India \\ ${ }^{2}$ Department of Soil Science and Agricultural Chemistry, Bihar Agricultural University, \\ Bhagalpur, Bihar-813210, India \\ *Corresponding author
}

\begin{abstract}
Keywords
Rock phosphate, Rhizobacteria, Mycorrhiza, Nutrients, Rice

Article Info

Accepted:

04 January 2019

Available Online:

10 February 2019
\end{abstract}

\section{A B S T R A C T}

Preparation of compost enriched with rock phosphate may be considered as a suitable option for utilizing the reserves of low-grade rock phosphate for enhancing the phosphorus use efficiency of crops. This research was carried out to study the effect of combined inoculation of mycorrhiza and selected rhizobacteria on soil nutrients and $\mathrm{P}$ uptake by rice. The experiment was conducted in Randomized Block Design with 10 treatments having three replications. The treatments included a control and a complete recommended fertilizer dose along with different combinations of rock phosphate enriched compost, mycorrhiza and rhizobacterial isolates at a lower P dose. Results from laboratory analysis of experimental soil and plant samples suggest that the treatment with rock-phosphate enriched compost @100\% of the phosphorus dose along with phosphorus solubilizing bacteria and mycorrhiza proved to be the most effective treatment for maintaining a higher nutrient status in soils. On the other hand, rock-phosphate enriched compost @ 50\% of the phosphorus dose amended with $50 \%$ of the recommended phosphorus from chemical fertilizers along with co-inoculation of phosphorus solubilizing bacteria and mycorrhiza resulted in a higher $\mathrm{P}$ uptake by rice. Co-inoculation of microbial inoculants in presence of organic matter can be considered as possible strategies towards improving nutrient status in soils as well as P nutrition to plants for a sustainable soil health.

\section{Introduction}

Phosphorus $(\mathrm{P})$ is the most limiting macronutrient after nitrogen in most of the Indian soils and Bihar is no different. Low phosphate availability in soils may be attributed to high phosphate fixation (60 to
$70 \%$ ) by hydroxides of iron and aluminium and calcium carbonate when water soluble Pfertilizer is applied. This leads to poor yield of rice (Ghosal et al., 2012). Currently, a majority of the phosphatic fertilisers are imported and thus prove to be expensive for most of the resource-poor farmers in the country. Mineral wealth acts as the major 
resource for fertilizers which is finite and non-renewable. Thus, the optimal and economic use of this precious resource holds great importance. Although, local phosphate deposits exist in India, some of them are still unexploited and most of them are of lowgrade (Tarafdar, 2013). Rock phosphate has good P content (28-30\%) but it cannot be directly used as a fertilizer owing to the poor release of plant available $\mathrm{P}$ (Reddy et al., 2002). The ability of the rock phosphate to release phosphates in plant available forms depends on their particle size, chemical and mineralogical characteristics as well as the properties of the soil in which they are applied. Also, solubility of phosphorus increases with the increase in organic matter content in soil. Moreover, farmyard manure (FYM) and traditional compost contain very small amount of nutrients, particularly $\mathrm{P}$ which are difficult to obtain in required quantity for substituting some part of chemical fertilizers. Rock phosphate enriched compost is a potent and suitable alternative for FYM or traditional compost to sustain soil physical, chemical and biological quality. Arbuscular mycorrhizal fungi (AMF) improve the phosphorus nutrition after colonizing the roots of host plants growing on soils with low or sparingly soluble forms of $\mathrm{P}$ (Shenoy and Kalagudi, 2005). On the other hand, beneficial rhizobacteria, also termed as plantgrowth-promoting rhizobacteria (PGPR) (Sikora, 1992), release low molecular weight organic acids (esp. Gluconic and ketogluconic acid) which dissolve phosphatic minerals (He et al., 2002). Certain identified phosphorus solubilizing bacteria like Pseudomonas striata can help in solubilizing the native soil $\mathrm{P}$ for increased availability to the plants. Not only providing phosphorus to the plants, the phosphate solubilizing microorganisms are also reported to facilitate the growth of plants by stimulating the efficiency of nitrogen fixation, accelerating the accessibility of other trace elements and by synthesizing important growth promoting substances (Mittal et al., 2008).

There is great possibility to save our rock phosphate reserve as well as a huge amount of capital spent on raw materials to prepare $\mathrm{P}$ fertilisers by preparation and use of compost enriched with rock phosphate. In this paper, an attempt was made to study the combined effect of rock phosphate-enriched compost and microbial inoculants on soil fertility and enzymatic activity.

\section{Materials and Methods}

\section{Details of the experiment}

A field experiment with rice (VarietyRajendra Mahsuri) as the test crop was conducted at the Research Farm of Bihar Agricultural University, Sabour, Bhagalpur (Bihar). The experiment was laid out with 10 treatments (replicated thrice) in a Randomized block design (Table 1).

\section{Soil sampling}

The surface soil samples $(0-15 \mathrm{~cm}$ depth) were collected from each treatment after harvest of rice crop. They were air-dried, processed and passed through a $2.00 \mathrm{~mm}$ aperture sieve for further laboratory analysis.

\section{Laboratory analysis of Soil and plant samples}

\section{Status of soil before initiation of the experiment}

The initial experimental soil was analysed in the laboratory for important soil parameters like pH (Jackson, 1973), electrical conductivity (Jackson, 1973), oxidisable organic carbon (Walkley and Black, 1934), mineralizable N (Subbaiah and Asija, 1956), available Olsen's P (Olsen, 1954), available K 
(Jackson, 1973) and DTPA-extractable micronutrients (Lindsay and Norvell, 1978). As evident from the results obtained, the soil was found to be alkaline with $\mathrm{pH}$ of 7.70 , had an EC of $0.118 \mathrm{dS} / \mathrm{m}$ which suggests the absence of salinity and the organic carbon content $(0.59 \%)$ was in the medium range. As far as the nutrient level is concerned, the soil had low mineralizable $\mathrm{N}$ content $(163.18 \mathrm{~kg}$ $\left.\mathrm{ha}^{-1}\right)$, medium $\mathrm{P}\left(15.89 \mathrm{~kg} \mathrm{ha}^{-1}\right)$, medium $\mathrm{K}$ $\left(209.32 \mathrm{~kg} \mathrm{ha}^{-1}\right)$. DTPA extractable Fe, Mn, $\mathrm{Cu}$ and $\mathrm{Zn}$ contents of $16.24 \mathrm{ppm}, 14.06 \mathrm{ppm}$, $0.77 \mathrm{ppm}$ and $0.61 \mathrm{ppm}$ respectively was recorded for the initial soil sample collected.

\section{Results and Discussion}

\section{Effect of treatments on soil properties}

\section{Soil pH, EC and organic carbon content}

The different treatments in the experiment were found to have no significant effect on the soil $\mathrm{pH}$, electrical conductivity and organic carbon content (Figure 1). However, cropping and introduction of organic amendments led to a numerical decrease in the $\mathrm{pH}$ of soil (although insignificant) which may be attributed to the release of organic acids from the root biomass and microbial decomposition.

\section{Plant-available nutrients in soil}

The plant-available contents of major nutrients viz., $\mathrm{N}, \mathrm{P}, \mathrm{K}, \mathrm{Fe}, \mathrm{Mn}, \mathrm{Cu}$ and $\mathrm{Zn}$ as influenced by the various treatments used in the experiment are presented in Figures 2 and 3. The treatment T6 i.e. RPC @ 100\% of the RDP dose + PSB + VAM was found to result in a higher content of available nutrients in the soil in comparison to other treatments after the harvest of Rice crop. The soil nitrogen content under the treatment was $180.84 \mathrm{~kg} \mathrm{ha}^{-1}$ where the magnitude of increase from control $\left(155.75 \mathrm{~kg} \mathrm{ha}^{-1}\right)$ was $16.10 \%$. Available $\mathrm{P}$ and $\mathrm{K}$ content were recorded to be $18.21 \mathrm{~kg} \mathrm{ha}^{-1}$ and $226.30 \mathrm{~kg}$ $\mathrm{ha}^{-1}$ respectively for T6 which showed an increase of $20.38 \%$ and $10.43 \%$ respectively over the control treatment. Content of DTPAextractable cationic micronutrients in soil were also highest for T6. The values were $18.67 \mathrm{mg} \mathrm{kg}^{-1}, 15.74 \mathrm{mg} \mathrm{kg}^{-1}, 0.85 \mathrm{mg} \mathrm{kg}$ and $0.64 \mathrm{mg} \mathrm{kg}^{-1}$ for $\mathrm{Fe}, \mathrm{Mn}, \mathrm{Cu}$ and $\mathrm{Zn}$ respectively and are significantly higher than control and at par with complete dose of recommended fertilizers.

Table.1 Details of treatments applied in the experiment

\begin{tabular}{|c|c|c|}
\hline Sl. No. & Treatments & \\
\hline 1. & T1 & Control (absolute) \\
\hline 2. & T2 & $100 \%$ RDF \\
\hline 3. & T3 & RPC @ $100 \%$ of the RDP dose \\
\hline 4. & T4 & RPC @ $100 \%$ of the RDP dose + PSB \\
\hline 5. & T5 & RPC @ $100 \%$ of the RDP dose + VAM \\
\hline 6. & T6 & RPC @ $100 \%$ of the RDP dose + PSB + VAM \\
\hline 7. & T7 & $50 \%$ RDP + RPC @ 50\% of the RDP dose \\
\hline 8. & T8 & $50 \%$ RDP + RPC @ $50 \%$ of the RDP dose + PSB \\
\hline 9. & T9 & $50 \%$ RDP + RPC @ $50 \%$ of the RDP dose + VAM \\
\hline 10. & T10 & $50 \%$ RDP + RPC @ $50 \%$ of the RDP dose + PSB + VAM \\
\hline
\end{tabular}

RDF- Recommended dose of fertilizers; RPC- Rock Phosphate enriched compost; RDP- Recommended dose of Phosphorus; PSB- Phosphorus solubilizing bacteria (@ $20.0 \mathrm{~g} \mathrm{~kg}^{-1}$ seed); VAM- Vesicular Arbuscular Mycorrhiza (@ $10 \mathrm{~kg} / \mathrm{ha}$ inoculum) 
Fig.1 Effect of different treatments on $\mathrm{pH}, \mathrm{EC}$ and organic carbon content in post-harvest soils

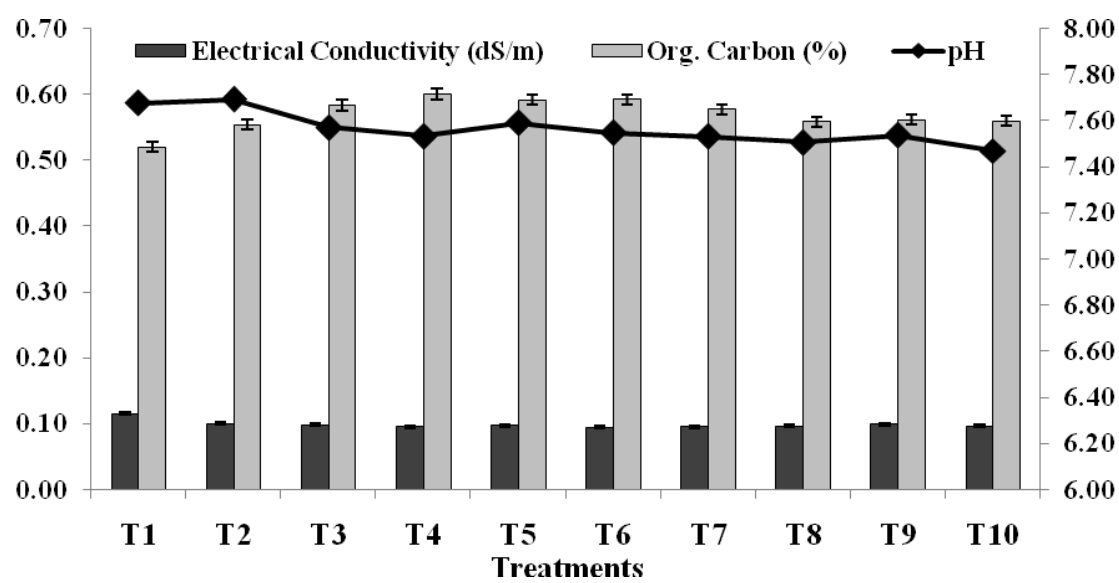

Fig.2 Effect of different treatments on mineralizable N, available $\mathrm{P}$ and $\mathrm{K}$ in post-harvest soils

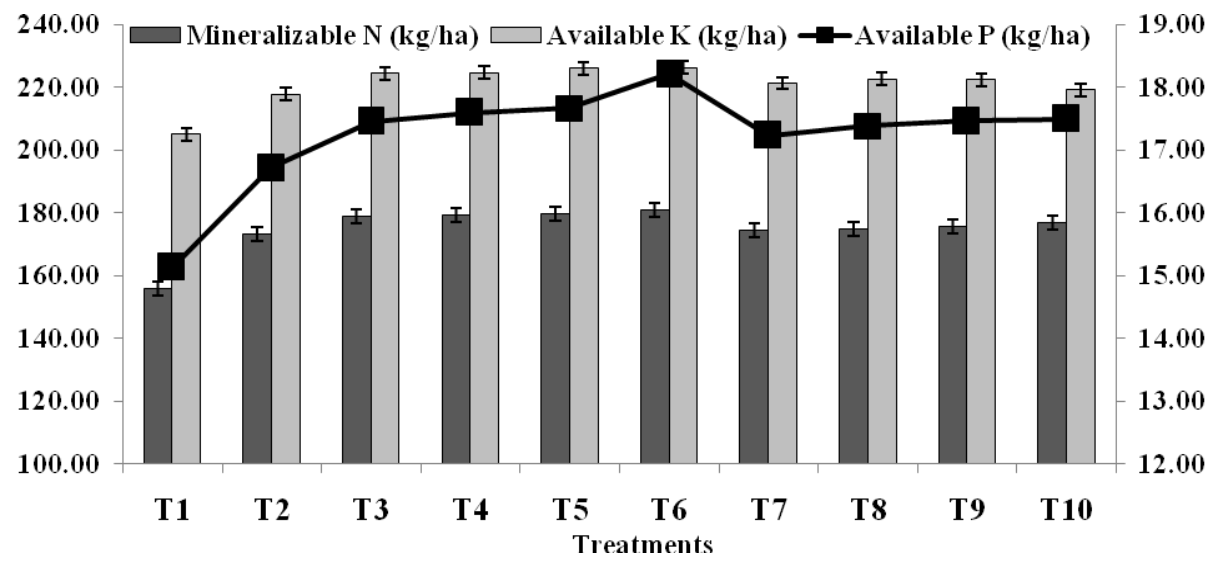

Fig.3 Effect of different treatments on DTPA-extractable micronutrients in post-harvest soils

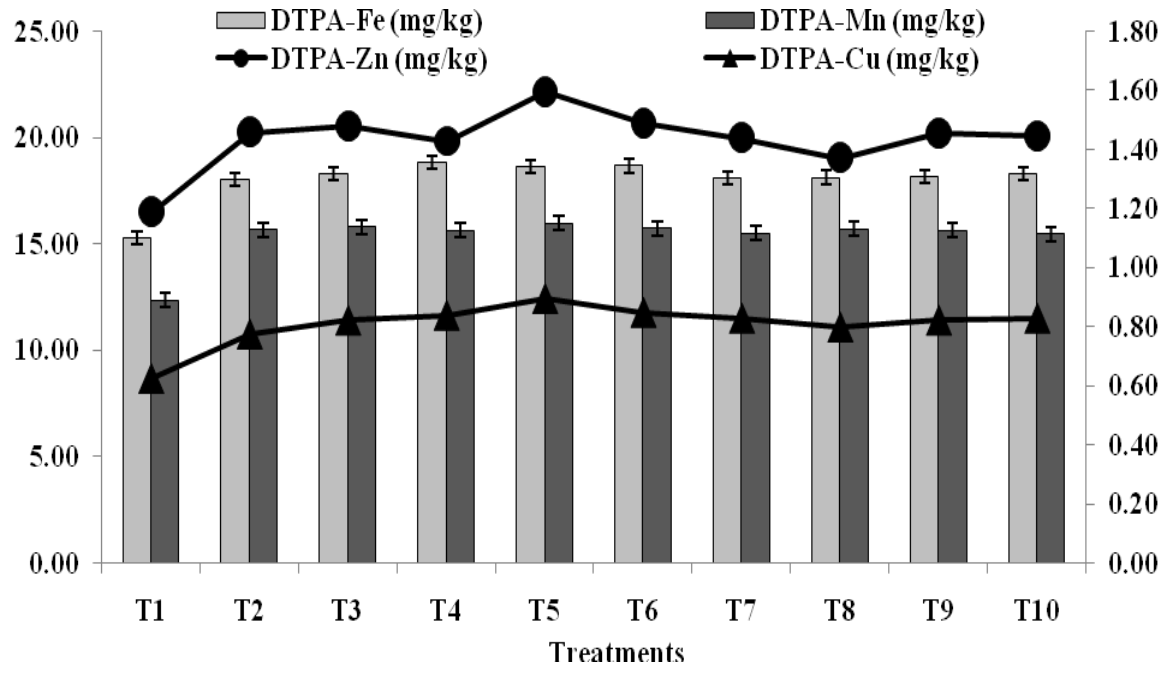


Fig.4 Effect of different treatments on P uptake by rice

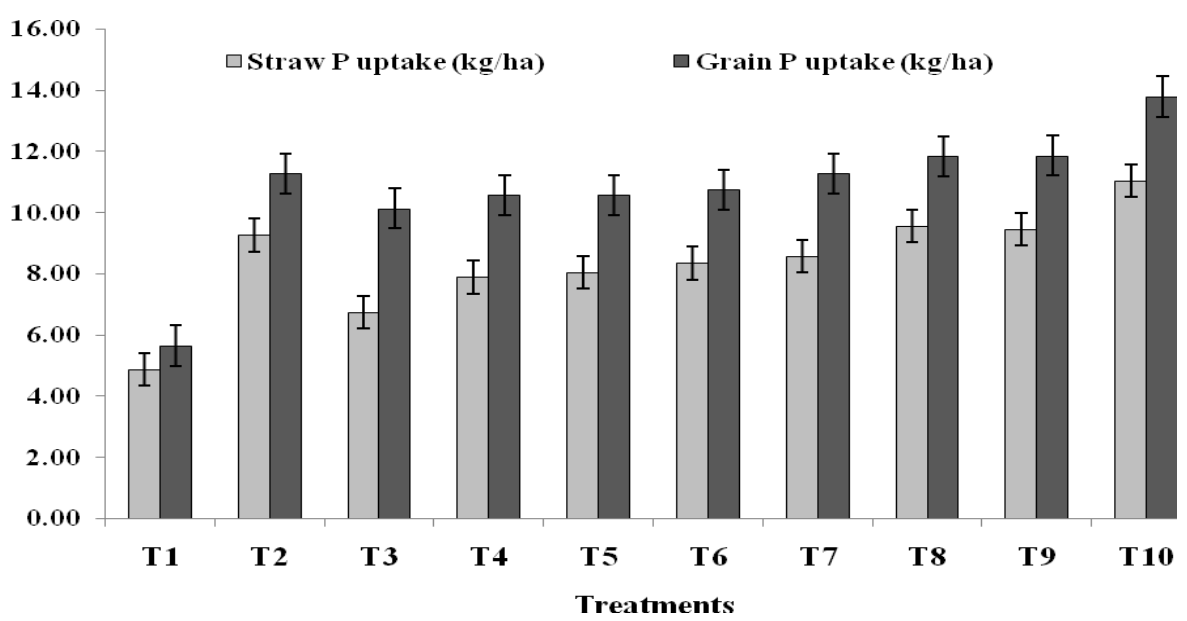

The enhancement in available P content may be attributed to the combined effect of enriched compost with phosphorus solubilizers which help in dissolution of fixed $\mathrm{P}$ from soil colloids as well as from the rock phosphate used in compost preparation. Mycorrhiza which chiefly act as the nutrient mobilizers due to extension of plant roots also helps in nutrient solubilisation to some extent. These results corroborate with findings of Ali et al., (2014) who reported that composted rock phosphate with organic material significantly increased the content of nutrients in soil (Fig. 3).

\section{Phosphorus uptake by rice}

Results for phosphorus by rice as affected by the different treatments have been presented in Figure 4. Highest $P$ uptake both by grain (13.78 $\left.\mathrm{kg} \mathrm{ha}^{-1}\right)$ and straw $\left(11.03 \mathrm{~kg} \mathrm{ha}^{-1}\right)$ was recorded for the treatment T10 i.e. $50 \%$ RDP + RPC @ $50 \%$ of the RDP dose + PSB + VAM. The magnitude of increase in the uptake over control was found to be $144.39 \%$ and $126.17 \%$ for grain and straw respectively. Result for $\mathrm{P}$ uptake was highest for T10 while the soil nutrient contents were recorded to be highest for T6. This may be due to the fact that the provision of readily available $\mathrm{P}$ in the form of soluble fertilizers leads to a higher uptake by plants in comparison to the organic source of the nutrient. (Kothari et al., 1991) suggesting that VAM fungi increase the uptake of many nutrients including Beura et al., (2016) also observed that that the inclusion of AM fungal inoculation in a treatment can effectively increase the plant phosphorus uptake. Bharti et al., (2017) also reported that the co-inoculation of mycorrhiza with phosphorus solubilizers was the most effective treatment in terms of enhanced $\mathrm{P}$ uptake in maize.

Indian phosphate rock reserves which are considered to be low grade can be used as effective soil fertility amendments by preparation of enriched compost and their conjunctive application with microbial inoculants like Phosphorus solubilizing bacteria and mycorrhizal isolates is a promising measure to improve the plant-available nutrients in soil along with the $\mathrm{P}$ uptake by plants.

\section{Acknowledgement}

The authors acknowledge the support of Bihar Agricultural University in form of provision of experimental area and laboratory facility for the research.

\section{References}

Ali, A., Sharif, M., Wahid, F., Zhang, Z., Shah, S.N.M., Rafiullah, Zaheer, S., Khan, F. and Rehman, F. 2014. Effect of Composted Rock Phosphate with Organic Materials on Yield and Phosphorus 
Uptake of Berseem and Maize. Am. J. Plant Sci., 5: 975-984.

Beura, K. S., Singh, M., Pradhan, A. K. Rakshit, R and Lal, M. 2016. Evaluation of Arbuscular Mycorrhiza Fungi Species for Their Efficiency Towards Nutrient Acquisition in Rhizospheric Soil of Maize. International Journal of Bioresource and Stress Management, 7: 130135.

Bharti, K. P. 2017. Effect of Co-inoculation of Arbuscular Mycorrhizal Fungi and Plant Growth Promoting Rhizobacteria on Soil Zinc Dynamics. M.Sc. thesis, Bihar Agricultural University, Bihar, India.

Ghosal, P. K. And Chakraborty, T. 2012 Comparative Solubility Study of Four Phosphatic Fertilizers in Different Solvents and the Effect of Soil. Resources and Environment, 2(4): 175-179.

He, Z.L., Bian, W and Zhu, J. 2002. Screening and identification of microorganisms capable of utilizing phosphate adsorbed by goethite. Comm. Soil Sci. Plant Anal., 33:647-663.

Jackson, M. L. 1973. Soil Chemical Analysis, Prentice Hall, New Delhi, 32: 34-36.

Kothari, S. K., Marschner, H. and Romheld, V. 1991. Contribution of the VA mycorrhizal hyphae in acquisition of phosphorus and zinc by maize grown in a calcareous soil. Plant Soil, 131: 177-185.

Lindsay, W. L. and Norvell, W. A. 1978. Development of DTPA soil test for zinc, iron, manganese and copper. Soil Sci. Soc. American J., 42: 421-428.

Mittal, V., Singh, O., Nayyar, H., Kaur, J. and
Tewari, R. 2008. Stimulatory effect of phosphate solubilizing fungal strains (Aspergillus awamori and Penicillium citrinum) on the yield of chickpea (Cicer arietinum L. cv. GPF2). Soil Biol. Biochem., 40:718-727.

Olsen, S.R., Cole, C.V., Watanable, F.S. and Dean, L.A. 1954. Estimation of available phosphorus on soil by extraction with sodium bicarbonate. USDA Circular Nr. 939, Washington, D.C: US Gov. Print. Office.

Reddy, M.S., Kumar, S. and Khosla, B. 2002. Biosolubilization of poorly soluble rock phosphates by Aspergillus tubingensis and Aspergillus niger. Biores. Technol., 84:187-189.

Shenoy, V.V. and Kalagudi, G.M. 2005. Enhancing plant phosphorus use efficiency for sustainable cropping. Biotechnology Advances, 23: 501-513.

Sikora, R.A. 1992 Management of the antagonistic potential in agricultural ecosystems for the biological control of plant parasitic nematodes. Аnnu Rev Phytopathol., 30:245-270.

Subbiah, B.V. and Asija, C.L. 1956. A rapid procedure for the estimation of available nitrogen in soils. Curr. Sci., 25: 328.

Tarafdar, J.C. 2013. Phosphorus- A Bright Future Ahead! Journal of Indian Society of Soil Science, 61: 29-37.

Walkley, A. H. and Black, I. A. 1934. An examination of the Degtjareff method for determining soil organic carbon and a proposed modification of the chromic acid titration method. Soil Sci., 37: 29-38.

\section{How to cite this article:}

Kasturikasen Beura, Amit Kumar Pradhan, Goutam Kumar Ghosh and Anshuman Kohli. 2019. Combined Effect of Enriched Compost and Microbial Inoculants on Soil Nutrients and Phosphorus Uptake by Rice. Int.J.Curr.Microbiol.App.Sci. 8(02): 176-181. doi: https://doi.org/10.20546/ijcmas.2019.802.021 